The meeting of the British Association at Ipswich in 1895 was marked by the reappearance of Mr. Harmer, to the great surprise of a generation that had come to regard his work as finished. He presented two important papers upon the Coralline and Red Crags, which were received with great interest and attention by newcomers in the field of Pliocene geology and also by distinguished workers from France and Belgium present at the meeting.

From this time until the end of his life Mr. Harmer's interest and activity never flagged. He again took to the field and contributed many important papers to the Geological Society and other bodies. In Pliocene geology his achievements were many and valuable. The discovery of a deposit of Red Crag at Little Oakley, which yielded to his minute and pertinacious investigation a fauna of unparalleled richness, led him to a general review of the Pliocene geology of East Anglia, giving definiteness to the opinion long held by workers in that field that the deposits of Red Crag age marked successive stages in the withdrawal of the North Sea from south to north.

A discussion of the fragmentary Upper Tertiary patches of Lenham gave occasion for the correlation of the British Pliocenes with those of Belgium and Holland. His achievements in this field of study have the enthusiastic recognition of the geologists of Holland, Belgium, and France.

The remarkable contrast presented by the contem porary Pliocene deposits of the two sides of the North Sea in regard to the abundance of shells led to investigations of great moment. Premising that shells are cast up in profusion on the Dutch coast by the prevalence of onshore winds, Mr. Harmer showed that in Pliocene times the western shores received the shelly beaches. He proceeded from this to an elaborate discussion of the meteorology of the Pliocene and Glacial Periods, the first attempt by any man of science to apply the methods and results of modern meteorology to the solution of geological problems. This pioneer work has been followed up by many writers, notably in the recent book "The Evolution of Climate" by Mr. C. E. P. Brooks, to whom Harmer's work was apparently unknown.

The many additions to the Molluscan fauna of the Upper Tertiaries rendered necessary the resumption of the work of description interrupted by the death of the elder Searles Wood. Mr. Harmer undertook the task, and it is gratifying to know that shortly before the accident by which his death was accelerated he had revised the final proofs of the last of a series of supplements to the monograph on the Crag Mollusca published by the Palæontographical Society.

The great value of Mr. Harmer's work was recognised by his geological brethren ; from the Geological Society he received the Murchison medal; he was elected successively Membre Associé Étranger and Membre Honoraire of the Belgian Geological Society; and the University of Cambridge conferred upon him the honorary degree of M.A.

Two of Mr. Harmer's sons, adopted a scientific career, in which they have attained very high distinction; the elder, Sir Sidney F. Harmer, is well known as the director of the Natural History Department of the British Museum; the other, Mr. William Douglas
Harmer, called at a very early age to the position of warden of St. Bartholomew's Hospital-always regarded as a presage of future distinction--is now the senior surgeon in the throat department of the hospital.

Percy F. Kendall.

\section{Mr. M. DE C. S. Salter.}

THE death on May $2 \mathrm{I}$, after a short illness, of $\mathrm{Mr}$. Mortyn de Carle Sowerby Salter, at the early age of forty-two, removes from the scientific world an extremely able worker just at the moment when the mastery he had attained in his special field of study had brought him in sight of important achievements. The son of Mr. M. J. Salter, he was educated at Bancroft's school, and passed directly, at the age of sixteen years, to an assistantship in the British Rainfall Organisation under its founder Mr. G. J. Symons. Here he developed an aptitude for statistics and a patience with detailed routine which enabled him later to grasp the scientific principles underlying the distribution of rain and develop an enthusiasm for research combined with sagacity in the practical application of his knowledge.

Mr. Salter became my chief assistant at Camden Square in 1907 , and from I912 onwards relieved me of the whole responsibility for the accuracy of the annual rainfall tables in "British Rainfall." In I9I4 he was appointed assistant-director and in r9r 8 jointdirector of the Organisation, and on the transfer to the Meteorological Office of the Air Ministry in I9rg he became the first superintendent-in-charge, and was thus able to make the transition from private to official management easy for the five thousand voluntary observers.

Mr. Salter's health was always precarious, but he was nevertheless an indefatigable worker, and to the fact that no Medical Board would pass him for any form of military service is probably due the survival of the long-established system of rainfall investigation throughout the years of the War.

Mr. Salter served on the council of the Royal Meteorological Society and as a vice-president for many years; and he was an active member of the Institution of Water Engineers. He contributed numerous papers to these societies and to the Meteorological Magasine, of which he was joint-editor since I913. He took a considerable part in the compilation of annual rainfall maps of the British Isles and of large-scale rainfall maps of many counties and other areas in co-operation with me, and after my retirement he carried the rainfall mapping of the country far towards completion. His little book "The Rainfall of the British Isles," published in r92I, gives an excellent account of the existing state of knowledge on the subject. In a paper on the fluctuations of annual rainfall considered cartographically, in collaboration with Mr. J. Glasspoole, read to the Royal Meteorological Society during his last illness, Mr. Salter gave an important discussion of the regional relations of rainfall and atmospheric pressure full of promise for future development.

For twenty-three years I found Mr. Salter a loyal fellow-worker and faithful friend, keenly intelligent, absolutely trustworthy, full of sympathy and con-

$$
\text { NO. } 2797 \text {, VOL. I I I] }
$$


sideration. I have pictured him writing my obituary notice; I never thought the natural order would be reversed. Hugh Robert Mill.

\section{Prof. E. HaGen.}

The issue of the Physikalische Zeitschrift for April I contains the account of the life and work of the late Prof. E. Hagen given by Prof. E. Gümlich at the meeting of the German Physical Society on March 9. Prof. Hagen was born at Königsberg on January 3I, I85I, and losing his mother, who was the youngest daughter of Bessel the astronomer, in 1856 , was brought up by a stepmother for whom he had a lifelong affection. On the removal of his father to Berlin he became a pupil at the local Gymnasium and in $187 \mathrm{I}$ entered the University. After two years there he went to Heidelberg, where he graduated in 1875 , having in the meantime acted as assistant to Bunsen. The next two years he spent at Dresden as assistant to Toepler and a further six as assistant to Helmholtz at Berlin.

In 1883 Hagen became a lecturer in the University of Berlin, and next year extra professor of applied physics at the Dresden Polytechnic. In 1887 he became physicist to the Navy and, removing to Kiel, acted also as extra professor at the University. In I893 he became director of the technical section of the Reichsanstalt at Charlottenburg. He married in 1896 the daughter of Von Bezold the meteorologist, and in I904 joined the staff of the German Museum at Munich. He died of inflammation of the knee on January I5. He was best known in this country for his work in conjunction with Rubens on the connexion between the electrical conductivity and the radiating and reflecting powers of metals.
IT is with much regret that we record the death of Dr. Elizabeth Acton, on Sunday, May I3, after a prolonged illness. Dr. Acton was a distinguished student of the late Prof. G. S. West in the botanical department of the University of Birmingham. In 1908 she took her Bachelor of Science degree with honours, and in the following year received the M.Sc. for research work in botany. After that time she was almost continuously engaged in botanical research, and in rgr6 was awarded the degree of D.Sc. (Birmingham). Her contributions to the study of fresh-water algæ are of outstanding value, and her work throughout was marked by great thoroughness and painstaking accuracy. Her early death has removed a devoted worker from the sphere of botanical research. Dr. Acton's activities outside her scientific work were necessarily limited, owing partly to her continuous ill-health and partly to her retiring disposition. She was a loyal friend, and her uncompromising honesty was one of her chief characteristics.

J. S. B. E

E. M. P.

WE regret to announce the following deaths :

Prof. J. Chiene, emeritus professor of surgery in the University of Edinburgh and a friend and disciple of Lord Lister, on May 29, aged eighty.

Canon W. W. Fowler, president in rgor--2 of the Entomological Society, and author of "The Coleoptera of the British Islands," on June 3 , aged seventy-four.

Prof. Franz Neger, professor of botany in the Dresden Technical College and director of the Botanical Gardens there, who worked with Baeyer for several years and published a thesis on dehydracetic acid, aged fifty-four.

\section{Current Topics and Events.}

THE immense progress which has been made in the elucidation of crystal structure by means of X-rays, since the first discovery of von Laue at Munich in I9I2, and especially the quantitative development which has afforded the absolute distances separating the atoms, their actual sizes, and the dimensions of the space-lattice cells, is largely due to the invention of the ionising X-ray spectrometer by Sir William Bragg. The brilliant use made of that instrument at University College, London, and latterly also by an increasing number of other workers in various parts of the world, has been the means of accumulating a surprising amount of knowledge of the structure and structural dimensions of a large number of substances, many of the more recently studied of which are no longer of the simplicity of those first submitted to investigation. It must prove of interest, therefore, to our readers that we are able to present, as a supplement to the present issue, a revised form of an admirable lecture which was recently delivered by Sir William Bragg to the Royal Society of Arts. The most noteworthy fact which emerges from the accumulated results, including those derived from the photographic method of Laue and the powder methods of Debye, Scherrer, and Hull, is that the conclusions of crystallographers, based on the most accurate crystal measurement and on the perfected geometrical theory of crystal structure, are proved to be correct, both as regards the nature of that structure, and its relative unit-cell dimensions in those few cases in which it had been possible to determine them. These relative dimensions are now converted into absolute values by the X-ray spectrometric measurements. The recent venture into the more difficult field of organic substances is adding a further chapter of exceptional interest, and is of immense importance both to chemistry and to optics. The results have already had the happy effect of restoring the molecule to its proper place in the solid state, from which only a misreading of the first few results with the simplest inorganic compounds had temporarily displaced it. Moreover, they have rendered it clear that the number, nature, and arrangement of the external electrons of the atom itself are involved in cementing together the parts of the crystal structure, so that further work is bound to throw light on atomic structure, and possibly to decide between, or combine the correct portions of, the rival theories concerning it.

Circular No. 137, issued by the Bureau of Standards, U.S.A., is the fourth of a series of circulars describing very simple radio receiving sets which were originally prepared for use by the Boys' and 